\title{
Paenibacillus contaminans sp. nov., isolated from a contaminated laboratory plate
}

\author{
Jui-Hsing Chou, ${ }^{1}$ Jo-Hsin Lee, ${ }^{2}$ Mei-Chun Lin, ${ }^{2}$ Poh-Shing Chang, ${ }^{3}$ \\ A. B. Arun, ${ }^{1}$ Chiu-Chung Young ${ }^{1}$ and Wen-Ming Chen ${ }^{2}$ \\ ${ }^{1}$ Department of Soil Environmental Science, College of Agriculture and Natural Resources, National \\ Chung Hsing University, Taichung, Taiwan \\ ${ }^{2}$ Laboratory of Microbiology, Department of Seafood Science, National Kaohsiung Marine \\ University, No. 142, Hai-Chuan Rd, Nan-Tzu, Kaohsiung City 811, Taiwan \\ ${ }^{3}$ Department of Aquaculture, National Kaohsiung Marine University, Kaohsiung, Taiwan
}

Correspondence Wen-Ming Chen p62365@ms28.hinet.net
The genus Paenibacillus was created with 11 Bacillus spp. by Ash et al. (1993). Since its creation, several novel Paenibacillus species have been added to this diverse genus over the years. Presently, more than 70 species are recognized as members of the genus Paenibacillus (http:// www.bacterio.cict.fr/p/paenibacillus.html). Species belonging to the genus Paenibacillus have been isolated from various ecological niches such as soil, rhizosphere, phyllosphere, water, insect, food, faeces, blood cultures and Antarctic sediments. Few Paenibacillus members have been isolated from human biological samples and the possibility that these bacteria may cause human infection is of particular concern (Roux \& Raoult, 2004). Generally, members of this genus produce endospores, possess anteiso- $\mathrm{C}_{15: 0}$ as the major cellular fatty acid and have

The GenBank/EMBL/DDBJ accession number for the $16 \mathrm{~S}$ rRNA gene sequence of strain $\mathrm{CKOBP}^{-} \mathrm{G}^{\top}$ is EF626690.

An extended neighbour-joining phylogenetic tree based on 16S rRNA gene sequences showing the relationship between strain $\mathrm{CKOBP}^{-}{ }^{\top}$ and species of the genus Paenibacillus is available as supplementary material with the online version of this paper. genomic DNA $\mathrm{G}+\mathrm{C}$ contents in the range $39-54 \mathrm{~mol} \%$ (Shida et al., 1997).

The aim of the present study was to determine the taxonomic position of a novel Paenibacillus-like organism, isolated from a contaminated laboratory plate and designated strain CKOBP- $6^{\mathrm{T}}$, by using a polyphasic taxonomic approach.

The $\mathrm{pH}$ range for growth was examined in tryptic soy broth (BD Difco) using appropriate biological buffers ( $\mathrm{pH} 4-10)$ (Chung et al., 1995). Growth of the strain at various temperatures $\left(4,10,15,25,30,37,42\right.$ and $\left.45^{\circ} \mathrm{C}\right)$ was examined in tryptic soy broth adjusted to $\mathrm{pH} 7$. Tolerance of strains to various $\mathrm{NaCl}$ levels was tested in nutrient broth (BD Difco) adjusted to different $\mathrm{NaCl}$ concentrations $(0,0.5 \%$ and $1.0-10.0 \%, \mathrm{w} / \mathrm{v}$, at intervals of $1.0 \%)$. Growth was examined by measuring the turbidity $\left(\mathrm{OD}_{600}\right)$ of cultures grown at various $\mathrm{pH}, \mathrm{NaCl}$ concentrations and temperatures. Anaerobic cultivation was performed on nutrient agar (BD Difco) and tryptic soy broth agar using the Oxoid AnaeroGen system.

Strain CKOBP- $6^{\mathrm{T}}$ showed good growth on DNase test agar (BD Difco) compared to other complex media, such as tryptic soy, nutrient and LB media. On DNase test agar, 
strain $\mathrm{CKOBP}-6^{\mathrm{T}}$ formed visible, colourless, semi-transparent, circular colonies with entire edges; colonies were approximately $0.5-1.0 \mathrm{~mm}$ in diameter after $72 \mathrm{~h}$ incubation at $30{ }^{\circ} \mathrm{C}$. Strain CKOBP- $6{ }^{\mathrm{T}}$ showed good growth at $10-37{ }^{\circ} \mathrm{C}, 0-2 \% \mathrm{NaCl}$, and $\mathrm{pH} 6.5$ and 8 . Optimal growth was observed at $30{ }^{\circ} \mathrm{C}, 0.5 \% \mathrm{NaCl}$ and $\mathrm{pH}$ 7.0.

Cells were observed in the lag, exponential and stationary phases of growth under a phase-contrast microscope to ascertain cell shape and motility (hanging-drop method). Flagellum staining was performed using the Spot Test Flagella Stain (BD Difco). Gram Stain Set S (BD), the Ryu non-staining $\mathrm{KOH}$ method (Powers, 1995) and Bactident Aminopeptidase test strips (Merck) were used to ascertain Gram reaction. Poly- $\beta$-hydroxybutyrate granule accumulation was determined using light microscopy after staining cells with Sudan black (Smibert \& Krieg, 1981).

Cells of strain CKOBP- $6^{\mathrm{T}}$ stained Gram-variable in Gram staining tests. The $\mathrm{KOH}$ test and L-alanine aminopeptidase using Bactident Aminopeptidase test strips were negative, as reported previously for Gram-positive bacteria (Gregersen, 1978). Vegetative cells were rod-shaped, 0.8$1.0 \mu \mathrm{m}$ wide and $2.0-3.0 \mu \mathrm{m}$ long. Young cells were peritrichously flagellated. Ellipsoidal spores were formed in swollen sporangia. No accumulation of poly- $\beta$-hydroxybutyrate granules was observed.

Extraction of genomic DNA, PCR amplification and sequencing of 16S rRNA genes were carried out as described by Chen et al. (2001). Sequence analysis was performed using a DNA sequencer (ABI PRISM 310; Applied Biosystems) and Fragment Assembly System program from the Wisconsin Package 8.1 (GCG, 1995) supplied by the National Health Research Institute of Taiwan. The resultant sequence was compared with corresponding results taken from the GenBank/EMBL/ DDBJ and RDP II databases for representatives of genera classified in the order Bacillales. Multiple sequence alignment of strain CKOBP- $6^{\mathrm{T}}$ with its closest relatives was performed using the software BIOEDIT (Hall, 1999) and MEGA version 3.1 (Kumar et al., 2004). Phylogenetic trees were inferred using the maximum-likelihood (Felsenstein, 1981), maximum-parsimony (Kluge \& Farris, 1969) and neighbour-joining (Saitou \& Nei, 1987) algorithms. The unrooted tree topologies were evaluated by bootstrap analyses of the neighbour-joining dataset (Felsenstein, 1993). A nearly complete 16S rRNA gene sequence (1472 nt) was obtained for strain CKOBP-6 ${ }^{\mathrm{T}}$. A comparison of this sequence with those of representatives of genera classified in the order Bacillales showed that the organism fell within the evolutionary radiation occupied by the genus Paenibacillus. The maximum 16S rRNA gene sequence similarity between strain $\mathrm{CKOBP}-6^{\mathrm{T}}$ and the type strains of members of the genus Paenibacillus was $94.6 \%$. It is evident from the phylogenetic trees based on the neighbour-joining algorithm in Fig. 1 and Supplementary Fig. S1 (available in IJSEM Online) that strain CKOBP- $6^{\mathrm{T}}$ clearly formed a monophyletic branch in the genus Paenibacillus. The organism was most closely related to Paenibacillus chitinolyticus NBRC $15660^{\mathrm{T}}$, sharing a $16 \mathrm{~S}$ rRNA gene sequence similarity of $94.6 \%$. Strain CKOBP- $6^{\mathrm{T}}$ also shared comparatively low $16 \mathrm{~S}$ rRNA gene sequence similarity with Paenibacillus gansuensis KCTC $3950^{\mathrm{T}}(93.8 \%)$ and Paenibacillus terrigena $\mathrm{A} 35^{\mathrm{T}}$ $(93.8 \%)$. Similar tree topologies were obtained in phylogenetic trees generated with maximum-parsimony and maximum-likelihood algorithms (data not shown).

DNA-DNA relatedness experiments were not carried out between strain CKOBP- $6^{\mathrm{T}}$ and its closest phylogenetic

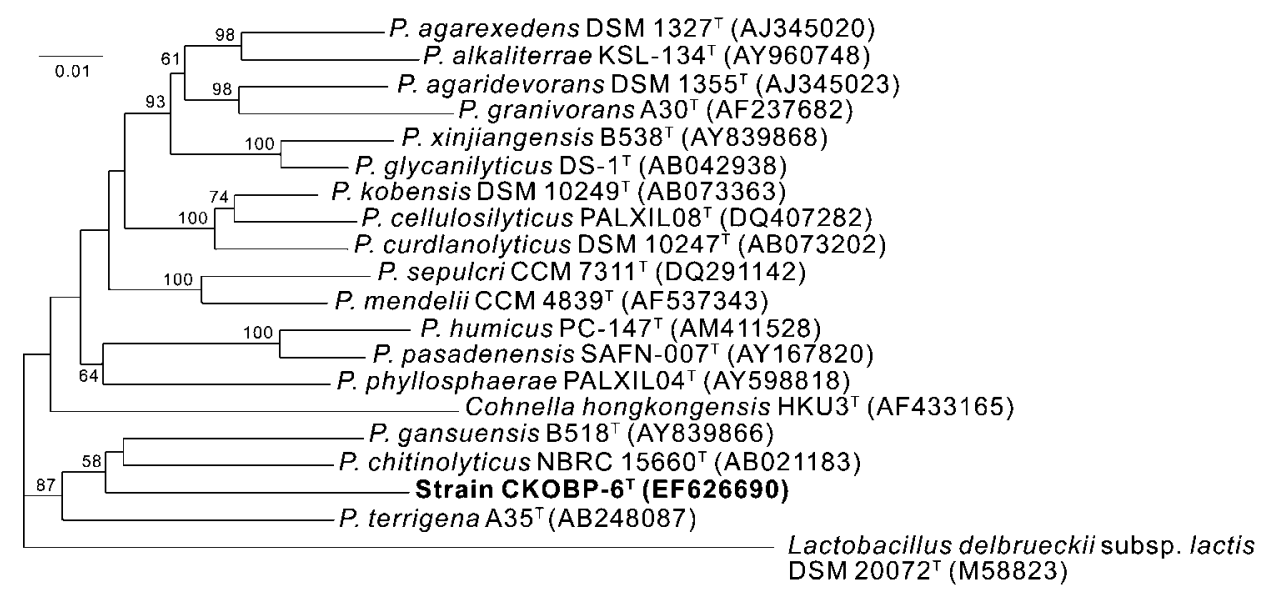

Fig. 1. Phylogenetic analysis based on $16 \mathrm{~S}$ rRNA gene sequences available from GenBank/EMBL (accession numbers are given in parentheses) constructed after multiple alignments of data showing the position of strain CKOBP- $6^{\top}$ in the genus Paenibacillus. Distances and clustering with the neighbour-joining method were determined using the software package BIOEDIT. Numbers at the nodes are percentage bootstrap values based on 1000 resampled datasets; only values above $50 \%$ are given. Bar, $0.01 \mathrm{nt}$ substitutions per nt. 
neighbours as the level of $16 \mathrm{~S}$ rRNA gene sequence similarity between strain $\mathrm{CKOBP}-6^{\mathrm{T}}$ and other Paenibacillus species was less than $95 \%$. It is now generally accepted that organisms displaying $3 \%$ or greater $16 \mathrm{~S}$ rRNA gene divergence are not members of the same species (Stackebrandt \& Goebel, 1994). Further evidence for the separate species status of the unidentified isolate comes from phenotypic considerations.

The DNA G $+\mathrm{C}$ content of strain $\mathrm{CKOBP}-6^{\mathrm{T}}$ was determined in duplicate as described by Mesbah et al. (1989). The G $+\mathrm{C}$ content was $52.1 \pm 1.0 \mathrm{~mol} \%$.

Chemosystematic studies were carried out to establish whether strain CKOBP- $6^{\mathrm{T}}$ had a chemical profile that was consistent with its assignment to the genus Paenibacillus. Biomass for chemical studies was grown in shake flasks of tryptic soy broth for 5 days at $37{ }^{\circ} \mathrm{C}$, checked for purity, harvested by centrifugation, washed twice in distilled water and freeze-dried. Polar lipids were extracted and analysed by using two-dimensional TLC as described by Ventosa et al. (1993). The major cellular phospholipids were phosphatidylglycerol, diphosphatidylglycerol, phosphatidylethanolamine and an unknown phosphoglycolipid. Respiratory quinones of strain CKOBP- $6^{\mathrm{T}}$ were extracted, separated and identified as described by Collins (1985). An unsaturated menaquinone with seven isoprene units (MK7) was the predominant isoprenologue. The diagnostic cellwall amino acid of strain CKOBP- $6^{\mathrm{T}}$ was determined by using the TLC method (Staneck \& Roberts, 1974). The isolate contained meso-diaminopimelic acid (wall chemotype III). Cellular fatty acids were analysed as methyl ester derivatives by GC according to the instructions of the Microbial Identification System (MIDI; Microbial ID). The fatty acid profile of strain CKOBP- $6^{\mathrm{T}}$ contained mainly anteiso- $\mathrm{C}_{15: 0}$, iso- $\mathrm{C}_{16: 0}$ and $\mathrm{C}_{16: 0}$. All of these properties

Table 1. Whole-cell fatty acid compositions (\%) of strain CKOBP- $6^{\top}$ and related species

Strains: 1 , CKOBP $-6^{\mathrm{T}}$ (P. contaminans sp. nov.); 2, P. chitinolyticus NBRC $15660^{\mathrm{T}}$; 3, P. gansuensis KCTC $3950^{\mathrm{T}}$; 4, P. terrigena A35 ${ }^{\mathrm{T}}$. Data are from this study. -, Fatty acid contents of $<0.5 \%$ or not detected.

\begin{tabular}{|lclcc|}
\hline Fatty acid & $\mathbf{1}$ & $\mathbf{2}$ & $\mathbf{3}$ & $\mathbf{4}$ \\
\hline $\mathrm{C}_{14: 0}$ & 1.8 & 0.5 & 2.3 & 1.2 \\
$\mathrm{C}_{15: 0}$ & - & - & 0.5 & 3.5 \\
$\mathrm{C}_{16: 0}$ & 12.0 & 7.2 & 9.1 & 6.3 \\
$\mathrm{C}_{17: 0}$ & 0.5 & - & - & - \\
iso- $\mathrm{C}_{14: 0}$ & 2.7 & - & 2.4 & 2.1 \\
iso- $\mathrm{C}_{15: 0}$ & 6.5 & 7.8 & 8.3 & 4.3 \\
iso-C $16: 0$ & 16.4 & 7.2 & 10.4 & 13.2 \\
iso- $\mathrm{C}_{17: 0}$ & 2.5 & 3.9 & 4.7 & 1.7 \\
anteiso-C & 52.0 & 59.0 & 51.8 & 54.1 \\
anteiso- $_{17: 0}$ & 5.4 & 9.1 & 7.2 & 7.1 \\
$\mathrm{C}_{16: 1} \omega 11 c$ & - & - & 0.5 & - \\
iso- $\mathrm{C}_{17: 1} \omega 10 c$ & - & 0.5 & - & - \\
\hline
\end{tabular}

are typical of representatives of the genus Paenibacillus (Shida et al., 1997). The fatty acid profile of CKOBP- $6^{\mathrm{T}}$ was comparable, in general, to those of $P$. chitinolyticus NBRC $15660^{\mathrm{T}}, P$. gansuensis KCTC $3950^{\mathrm{T}}$ and $P$. terrigena $\mathrm{A} 35^{\mathrm{T}}$ (Lee et al., 2004; Lim et al., 2006; Xie \& Yokota, 2007) (Table 1).

Strain CKOBP- $6^{\mathrm{T}}$ was examined for a broad range of phenotypic and biochemical properties using the API 20E, API 20NE, API ZYM and API $50 \mathrm{CH}$ (bioMérieux) systems according to the manufacturer's instructions. Catalase, oxidase, DNase and urease tests were carried out as described by Lányi (1987). Lipase (corn oil) and hydrolysis of starch and casein were determined as described by MacFaddin (2000). Hydrolysis of Tweens 20, 40, 60 and 80 was detected using standard methods (Gerhardt et al., 1994). Additionally, sensitivity of strain CKOBP- $6^{\mathrm{T}}$ to different antibiotics was checked using antibiotic discs (Oxoid). Detailed results of biochemical characterization and antibiotic sensitivity are provided in Table 2 and the species description.

From the above data, it is evident that isolate CKOBP- $6^{\mathrm{T}}$ exhibits an overall fatty acid profile that is consistent with those of members of the genus Paenibacillus (Table 1). Phylogenetic analysis based on 16S rRNA gene sequencing further confirmed its provisional assignment and clearly demonstrated that strain $\mathrm{CKOBP}-6^{\mathrm{T}}$ represents an unknown subline within the genus Paenibacillus. Biochemically, strain CKOBP-6 ${ }^{\mathrm{T}}$ could be differentiated from other phylogenetically and biochemically related species in the genus Paenibacillus (Table 2). On the basis

Table 2. Phenotypic and biochemical characteristics that differentiate strain CKOBP- $6^{\top}$ from representatives of closely related Paenibacillus species

Strains: 1 , CKOBP- $6^{\mathrm{T}}$ (P. contaminans sp. nov.); 2, P. chitinolyticus NBRC $15660^{\mathrm{T}} ; 3$, P. gansuensis KCTC $3950^{\mathrm{T}} ; 4$, P. terrigena $\mathrm{A} 35^{\mathrm{T}}$. All data are from this study, except DNA $G+C$ content data for $P$. chitinolyticus NBRC $15660^{\mathrm{T}}$, P. gansuensis KCTC $3950^{\mathrm{T}}$ and $P$. terrigena $\mathrm{A} 35^{\mathrm{T}}$, which were from Kuroshima et al. (1996), Lim et al. (2006) and Xie \& Yokota (2007), respectively. +, Positive; -, negative; $\mathrm{w}$, weak response.

\begin{tabular}{|lcccc|}
\hline Characteristic & $\mathbf{1}$ & $\mathbf{2}$ & $\mathbf{3}$ & $\mathbf{4}$ \\
\hline Anaerobic growth & + & - & - & + \\
Catalase & + & + & - & + \\
Oxidase & + & + & - & + \\
Nitrate reduction & - & + & - & - \\
Acid production from: & & & & \\
$\quad$ Arabinose & w & - & + & - \\
$\quad$ Glucose & w & + & + & + \\
$\quad$ Lactose & - & + & + & + \\
$\quad$ Xylose & - & - & + & - \\
Hydrolysis of: & & & & \\
$\quad$ Casein & - & $\mathrm{w}$ & + & + \\
$\quad$ Starch & - & - & - & + \\
DNA G + C content $(\mathrm{mol} \%)$ & 51.2 & 51.3 & 50.0 & 48.1 \\
& & & & \\
\hline
\end{tabular}


of phenotypic, chemotaxonomic and phylogenetic evidence, it is apparent that strain CKOBP- $6^{\mathrm{T}}$ represents a novel species within the genus Paenibacillus, for which the name Paenibacillus contaminans sp. nov. is proposed.

\section{Description of Paenibacillus contaminans sp. nov.}

Paenibacillus contaminans (con.ta'mi.nans. L. part. adj. contaminans contaminating).

Facultatively anaerobic, Gram-variable, sporulating, motile and rod-shaped, $0.8-1.0 \mu \mathrm{m}$ in diameter and $2.0-3.0 \mu \mathrm{m}$ in length. Grows at $\mathrm{pH} 6.5-8.0,0-2.0 \% \mathrm{NaCl}$ and $10-37^{\circ} \mathrm{C}$. Positive for DNase, cytochrome oxidase and catalase. Negative for lipase (corn oil) and hydrolysis of skimmed milk, starch, and Tweens 20, 40, 60 and 80. Positive (API $20 \mathrm{E})$ for $\beta$-galactosidase, citrate utilization, acetoin production, and acid production from glucose, arabinose and rhamnose, but negative for arginine dihydrolase, lysine decarboxylase, ornithine decarboxylase, urease, trytophan deaminase, gelatinase, $\mathrm{H}_{2} \mathrm{~S}$ production, indole production, and acid production from mannitol, inositol, sorbitol, sucrose, melibiose and amygdalin. In the API 20NE enzyme assay, positive for $\beta$-galactosidase, aesculin hydrolysis and assimilation of glucose and maltose, but negative for nitrate reduction, indole production, glucose acidification, arginine dihydrolase, urease, gelatinase, and assimilation of arabinose, mannose, mannitol, $\mathrm{N}$-acetylglucosamine, caprate, adipate, malate, citrate and phenylacetate. In the API ZYM enzyme assay, positive for $\mathrm{C} 4$ esterase, leucine arylamidase, $\beta$-galactosidase and $N$-acetyl- $\beta$-glucosaminidase, but negative for alkaline phosphatase, C8 lipase, C14 lipase, valine arylamidase, cystine arylamidase, trypsin, $\alpha$ chymotrypsin, acid phosphatase, naphthol-AS-BI-phosphohydrolase, $\alpha$-galactosidase, $\beta$-glucuronidase, $\alpha$-glucosidase, $\beta$-glucosidase, $\alpha$-mannosidase and $\alpha$-fucosidase. The following carbon sources were utilized (positive with the API $50 \mathrm{CH}$ system): glycerol, D-glucose, methyl $\alpha$-Dglucopyranoside, amygdalin, arbutin, cellobiose, maltose, melibiose, sucrose, trehalose, gentiobiose and turanose. The following substrates were not utilized as carbon sources (negative with the API $50 \mathrm{CH}$ system): erythritol, D-arabinose, L-arabinose, D-ribose, D-xylose, L-xylose, Dadonitol, methyl $\beta$-D-xylopyranoside, D-galactose, D-fructose, D-mannose, L-sorbose, L-rhamnose, dulcitol, inositol, D-mannitol, D-sorbitol, methyl $\alpha$-D-mannopyranoside, $N$ acetylglucosamine, aesculin, ferric citrate, salicin, D-lactose, inulin, melezitose, raffinose, starch, glycogen, xylitol, Dlyxose, D-tagatose, D-fucose, L-fucose, D-arabitol, L-arabitol, potassium gluconate, potassium 2-ketogluconate and potassium 5-ketogluconate. Resistant to sulfamethoxazole $(23.75 \mu \mathrm{g})$ plus trimethoprim $(1.25 \mu \mathrm{g})$; sensitive to ampicillin $(10 \mu \mathrm{g})$, chloramphenicol $(30 \mu \mathrm{g})$, gentamicin $(10 \mu \mathrm{g})$, kanamycin $(30 \mu \mathrm{g})$, nalidixic acid $(30 \mu \mathrm{g})$, novobiocin $(30 \mu \mathrm{g})$, penicillin $\mathrm{G}(10 \mathrm{U})$, rifampicin $(5 \mu \mathrm{g})$, streptomycin $(10 \mu \mathrm{g})$ and tetracycline $(30 \mu \mathrm{g})$. The major fatty acid components are anteiso- $\mathrm{C}_{15: 0}$, iso- $\mathrm{C}_{16: 0}$ and $\mathrm{C}_{16: 0}$. The major cellular phospholipids are phosphatidyl- glycerol, diphosphatidylglycerol and phosphatidylethanolamine. MK-7 is the predominant isoprenologue.

The type strain is $\mathrm{CKOBP}^{\mathrm{T}} \mathrm{6}^{\mathrm{T}}\left(=\mathrm{BCRC} 17728^{\mathrm{T}}=\mathrm{LMG}\right.$ $24216^{\mathrm{T}}$ ), isolated from a contaminated laboratory plate. The DNA G + C content of the type strain is $51.2 \mathrm{~mol} \%$.

\section{Acknowledgements}

W.-M. C. was supported by grants from the National Science Council, Taipei, Taiwan, Republic of China (NSC 95-2320-B-022-001-MY2 and 96-2313-B-022-001-MY3).

\section{References}

Ash, C., Priest, F. G. \& Collins, M. D. (1993). Molecular identification of rRNA group 3 bacilli (Ash, Farrow, Wallbanks and Collins) using a PCR probe test. Proposal for the creation of a new genus Paenibacillus. Antonie van Leeuwenhoek 64, 253-260.

Chen, W. M., Laevens, S., Lee, T. M., Coenye, T., de Vos, P., Mergeay, M. \& Vandamme, P. (2001). Ralstonia taiwanensis sp. nov., isolated from root nodules of Mimosa species and sputum of a cystic fibrosis patient. Int J Syst Evol Microbiol 51, 1729-1735.

Chung, Y. C., Kobayashi, T., Kanai, H., Akiba, T. \& Kudo, T. (1995). Purification and properties of extracellular amylase from the hyperthermophilic archaeon Thermococccus profundus DT5432. Appl Environ Microbiol 61, 1502-1506.

Collins, M. D. (1985). Analysis of isoprenoid quinones. Methods Microbiol 18, 329-366.

Felsenstein, J. (1981). Evolutionary trees from DNA sequences: a maximum likelihood approach. J Mol Evol 17, 368-376.

Felsenstein, J. (1993). PHYLIP (phylogeny inference package), version 3.5c. Distributed by the author. Department of Genome Sciences, University of Washington, Seattle, USA.

GCG (1995). Wisconsin Package Version 8.1 Program Manual. Madison, WI: Genetics Computer Group.

Gerhardt, P., Murray, R. G. E., Wood, W. A. \& Krieg, N. R. (editors) (1994). Methods for General and Molecular Bacteriology. Washington, DC: American Society for Microbiology.

Gregersen, T. (1978). Rapid method for distinction of Gram-negative from Gram-positive bacteria. Eur J Appl Microbiol Biotechnol 5, 123127.

Hall, T. A. (1999). BioEdit: a user-friendly biological sequence alignment editor and analysis program for Windows 95/98/NT. Nucleic Acids Symp Ser 41, 95-98.

Kluge, A. G. \& Farris, F. S. (1969). Quantitative phyletics and the evolution of anurans. Syst Zool 18, 1-32.

Kumar, S., Tamura, K. \& Nei, M. (2004). MEGA3: integrated software for Molecular Evolutionary Genetics Analysis and sequence alignment. Brief Bioinform 5, 150-163.

Kuroshima, K.-I., Sakane, T., Takata, R. \& Yokota, A. (1996). Bacillus ehimensis sp. nov. and Bacillus chitinolyticus sp. nov., new chitinolytic members of the genus Bacillus. Int J Syst Bacteriol 46, 76-80.

Lányi, B. (1987). Classical and rapid identification methods for medically important bacteria. Methods Microbiol 19, 1-67.

Lee, J.-S., Pyun, Y.-R. \& Bae, K. S. (2004). Transfer of Bacillus ehimensis and Bacillus chitinolyticus to the genus Paenibacillus with emended descriptions of Paenibacillus ehimensis comb. nov. and Paenibacillus chitinolyticus comb. nov. Int J Syst Evol Microbiol 54, 929-933. 
Lim, J.-M., Jeon, C. O., Lee, J.-C., Xu, L.-H., Jiang, C.-L. \& Kim, C.-J. (2006). Paenibacillus gansuensis sp. nov., isolated from desert soil of Gansu Province in China. Int J Syst Evol Microbiol 56, 2131-2134.

MacFaddin, J. F. (2000). Biochemical Tests for the Identification of Medical Bacteria, 3rd edn. Baltimore, MD: Williams \& Wilkins.

Mesbah, M., Premachandran, U. \& Whitman, W. B. (1989). Precise measurement of the $\mathrm{G}+\mathrm{C}$ content of deoxyribonucleic acid by highperformance liquid chromatography. Int J Syst Bacteriol 39, 159-167.

Powers, E. M. (1995). Efficacy of the Ryu nonstaining KOH technique for rapidly determining gram reactions of food-borne and waterborne bacteria and yeasts. Appl Environ Microbiol 61, 3756-3758.

Roux, V. \& Raoult, D. (2004). Paenibacillus massiliensis sp. nov., Paenibacillus sanguinis sp. nov. and Paenibacillus timonensis sp. nov., isolated from blood cultures. Int J Syst Evol Microbiol 54, 1049-1054.

Saitou, N. \& Nei, M. (1987). The neighbor-joining method: a new method for reconstructing phylogenetic trees. Mol Biol Evol 4, 406425.

Shida, O., Takagi, H., Kadowaki, K., Nakamura, L. K. \& Komagata, K. (1997). Transfer of Bacillus alginolyticus, Bacillus chondroitinus, Bacillus curdlanolyticus, Bacillus glucanolyticus, Bacillus kobensis, and
Bacillus thiaminolyticus to the genus Paenibacillus and emended description of the genus Paenibacillus. Int J Syst Bacteriol 47, 289-298.

Smibert, R. M. \& Krieg, N. R. (1981). General characterization. In Manual of Methods for General Microbiology, pp. 409-443. Edited by P. Gerhardt, R. G. E. Murray, R. N. Costilow, E. W. Nester, W. A. Wood, N. R. Krieg \& G. B. Phillips. Washington, DC: American Society for Microbiology.

Stackebrandt, E. \& Goebel, B. M. (1994). Taxonomic note: a place for DNA-DNA reassociation and $16 \mathrm{~S}$ rRNA sequence analysis in the present species definition in bacteriology. Int J Syst Bacteriol 44, 846849.

Staneck, J. L. \& Roberts, G. D. (1974). Simplified approach to identification of aerobic actinomycetes by thin-layer chromatography. Appl Microbiol 28, 226-231.

Ventosa, A., Marquez, M. C., Kocur, M. \& Tindall, B. J. (1993). Comparative study of "Micrococcus sp." strains CCM 168 and CCM 1405 and members of the genus Salinicoccus. Int J Syst Bacteriol 43, 245-248.

Xie, C.-H. \& Yokota, A. (2007). Paenibacillus terrigena sp. nov., isolated from soil. Int J Syst Evol Microbiol 57, 70-72. 